\title{
Problems of loan population in Russia
}

\author{
Tatiana Kolmykova ${ }^{1}$, Nataliya Mashkina ${ }^{1}$, Oleg Aseev ${ }^{1 *}$, Tatiana Svetovtseva ${ }^{1}$ \\ ${ }^{1}$ Southwest State University, 50 let Oktyabrya, 94, 305040 Kursk, Russia
}

\begin{abstract}
The article is devoted to the consideration of such a phenomenon as the debt load of the country's population on the example of Russia. The term "debt" means the ratio between debt obligations and available income. Assessing the level of debt or, in other words, the debt burden of Russian citizens is relevant, because real disposable incomes have a rather long downward trend, and consumer unsecured lending is becoming more affordable, the amount of debt to Russians to creditors is increasing year by year, while the share of overdue liabilities, although not very large, still poses certain risks. This situation increases the level of debt to citizens, which poses serious challenges for the socio-economic development of the state, since excessive debt burden can lead to a crisis (as, for example, in the USA in 2008). Therefore, it is especially important to soberly assess the level of debt load and take appropriate measures in time to regulate it, in particular, to cool the consumer lending market as the most volatile segment of lending to individuals.
\end{abstract}

\section{Introduction}

Credit in modern conditions is of great importance for the socio-economic development of society. A special place in the monetary relations system is occupied by lending to individuals, represented mainly by consumer and mortgage loans [3]. Lending to the population expands the boundaries of effective demand and contributes to the relative equalization of living standards, because It makes it possible to satisfy the current need, by acquiring the necessary goods or services, if the accumulation of savings is not completed or seems impossible due to the small amount of income. Undoubtedly, all this has favorable consequences for citizens, for business, and for the state. However, lending to the population carries, in addition to the positive aspects, also probable threats, as it has only a temporary welfare enhancing effect. In the future, consumer opportunities, on the contrary, are reduced due to the fact that part of the income, sometimes significant, goes to debt servicing. In addition, often the difficult financial situation that has developed due to taking a loan forces a person to do it again in order to pay off the first debt or to provide himself with necessities, which indicates his falling into credit bondage [5].

This situation across the country poses a serious danger. A high level of the debt burden of the population means a decrease in real incomes, which is a challenge to social policy by the state and undermining economic development. Currently, concerns about the high debt burden of the Russian population have reached the level of federal power. Therefore, in this

\footnotetext{
* Corresponding author: olegavto@list.ru
} 
article it is necessary to assess the level of debt burden of citizens in the Russian Federation.

The result of the work was a study of the debt level of the Russian population. Also, the work examined the dynamics of incomes of Russian citizens, in particular those that are actually disposable. We paid special attention to the study of the volume of accounts payable of the population, as well as its structure. The situation in the market of microfinance organizations was also considered. An important aspect of this work was a review of innovations in legislation relating to the regulation of the debt burden of the population.

The main conclusion of the work was the conclusion that currently the debt load on the population of the Russian Federation is at a satisfactory level, however, under the existing conditions of the continuing decline in real disposable incomes and the growth of consumer and microfinance lending segments, the situation may get out of control. To avoid this, the Bank of Russia in October 2019 introduced a mandatory calculation of the debt burden indicator. However, so far this measure is not perfect, since large banks have previously taken into account PD when deciding on the approval of a loan. However, according to experts in the banking industry, even such innovations can to some extent improve the situation in the field of consumer lending as early as 2020 .

\section{Materials and methods}

The debt load of the population and the level of income are inextricably linked. Therefore, we consider the dynamics of income, wages and pensions [2].

Table 1. Dynamics of income, wages and pensions, percentage previous year.

\begin{tabular}{c|l|c|c|c|c|c|c}
\hline & & 2013 & 2014 & 2015 & 2016 & 2017 & 2018 \\
\hline \multirow{2}{*}{ Earnings } & nominee & 11.7 & 7.1 & 10.6 & 0.9 & 1.8 & 4.3 \\
\cline { 2 - 8 } & real disposable & 4.0 & -0.7 & -3.2 & -5.8 & -1.6 & -0.2 \\
\hline \multirow{2}{*}{ Wage } & rated & 11.9 & 9.1 & 5.1 & 7.9 & 6.7 & 9.9 \\
\cline { 2 - 8 } & real & 4.8 & 1.2 & -9.0 & 0.8 & 2.9 & 6.8 \\
\hline \multirow{2}{*}{ Pension } & rated & 9.7 & 8.8 & 11.2 & 3.4 & 4.0 & 3.7 \\
\cline { 2 - 8 } & real & 2.8 & 0.9 & -3.8 & -3.4 & 0.3 & 0.8 \\
\hline
\end{tabular}

It should be noted that the continued decline in real disposable income has been the most protracted in recent Russian history. In 2018, this indicator of the possibility of personal consumption and savings showed a reduction for the fifth consecutive year. Overall 5-year real drop in revenues was $10.8 \%$ compared to 2013 . This trend is largely driven by an increase in mandatory payments, including payments on loans.

The last 10 years the volume of loans to individuals had a strong tendency to increase. In value terms, retail loans in 2018 exceeded the volume of 2008 by almost 4 -fold (compared with consumer prices on average rose by $128 \%$ ). The amount of overdue loans also increased, and once it began to decline in 2016 [11].

The reasons that people make of delay on loans, are non-uniform. Among them are respectful, related to the difficult financial situation due to loss of job, illness, etc. However, about $10 \%$ of the Russian borrower fails to repay loans due to poor payment discipline, as a result of the current financial illiteracy. These citizens, referring to the bank can not soberly assess their ability to return the debt that results in non-payment or re-loan, sometimes under an impressive percentage. This is a direct way to the high debt load [1].

Table 2. Dynamics bank credit volumes population and loans with overdue payments.

\begin{tabular}{c|c|c|c}
\hline Year & Retail loans, mln. rubles & $\begin{array}{c}\text { Loans with payments overdue } \\
\text { more than 90 days, mln. Rubles }\end{array}$ & $\begin{array}{c}\text { The share of loans with } \\
\text { overdue payments, } \%\end{array}$ \\
\hline
\end{tabular}




\begin{tabular}{l|c|c|c}
\hline 2018 & 14516052 & 847922 & 5.8 \\
\hline 2017 & 11724100 & 915684 & 7.8 \\
\hline 2016 & 10445815 & 1014010 & 9.7 \\
\hline 2015 & 10268324 & 1104036 & 10.8 \\
\hline 2014 & 10928420 & 881382 & 8.1 \\
\hline 2013 & 9324891 & 540347 & 5.8 \\
\hline 2012 & 7170016 & 344585 & 4.8 \\
\hline 2011 & 4759178 & 293397 & 6.2 \\
\hline 2010 & 3661127 & 299459 & 8.2 \\
\hline 2009 & 3309447 & 307367 & 9.3 \\
\hline
\end{tabular}

According to the research bureau of credit histories "Equifax", as of May $201951 \%$ of Russia's population has at least one credit in the bank.

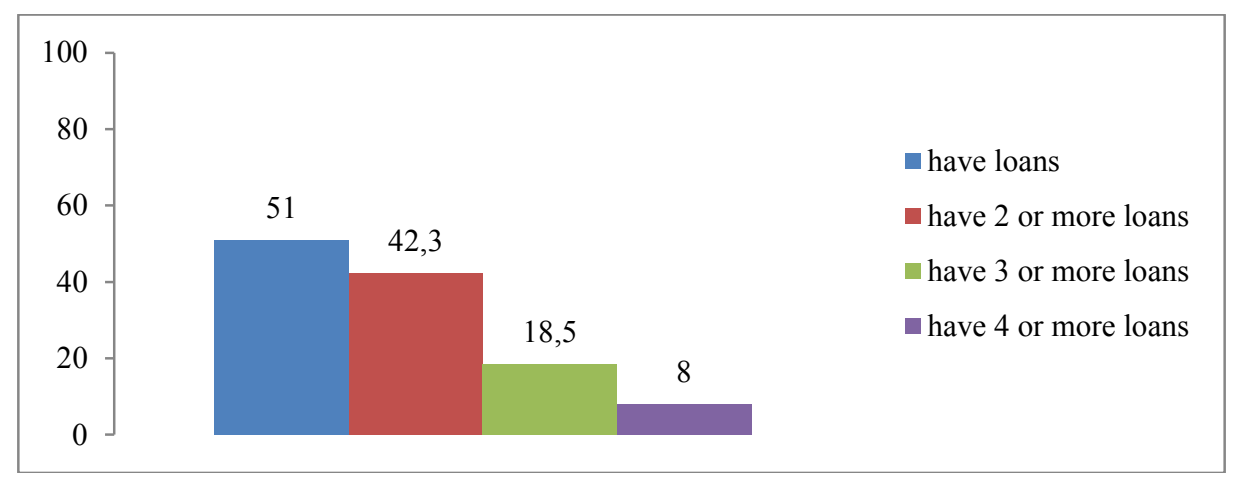

Fig. 1. Percentage of population with loans $\%$ in 2019 (in terms of number of debt).

At the same time $42.3 \%$ of the population in banks of two or more loan agreements at the same time, three or more $-18.5 \%$, nearly $8 \%$ of the population is served by four or more credits [9].

\section{Results and Discussion}

The level of debt load, which is calculated as the ratio of average debt to average annual household income on average in Russia rose to $28 \%$ in the first quarter of 2019. In some regions, the level of debt load exceeded 50\% (Kalmykia, Tuva). It rose more than $40 \%$ of households in zakreditovannost Chuvashia, Irkutsk region, Khanty-Mansi Autonomous District. Low rates are stored in the regions of the North Caucasus Federal District (Dagestan - 5\%, Ingushetia - 7\%, Chechnya - 7\%), as well as in the Crimea and Sevastopol (7\%) [10].

Table 3. Regions with the highest debt load of the population (in the first quarter of 2019).

\begin{tabular}{c|l|c|c}
\hline № & The subject of the Russian Federation & $\begin{array}{c}\text { The level of debt load, } \\
\%\end{array}$ & $\begin{array}{c}\text { The average amount of } \\
\text { debt, rubles. }\end{array}$ \\
\hline 1 & Republic of Kalmykia & 62 & 338042 \\
\hline 2 & Tyva Republic & 57 & 327620 \\
\hline 3 & Chuvash Republic-Chuvashia & 45 & 253103 \\
\hline 4 & Irkutsk region & 43 & 301978 \\
\hline 5 & Khanty-MansiyskAutonomous Area & 42 & 639273 \\
\hline 6 & Novosibirsk region & 40 & 302676 \\
\hline
\end{tabular}




\begin{tabular}{c|l|c|c}
\hline 7 & Tyumen region & 39 & 535179 \\
\hline 8 & Leningrad region & 39 & 324907 \\
\hline 9 & The Republic of Sakha (Yakutia) & 38 & 528635 \\
\hline 10 & The Republic of Mordovia & 38 & 204210 \\
\hline
\end{tabular}

All-Russian Public Opinion Research Center examined what categories of people increasingly taking loans. The most popular loans (mortgage and unsecured) use among young Russians aged 25 to 34 years. $72 \%$ of respondents in this age group said that they or members of their family has outstanding loans. In second place are the respondents aged 35 to 44 years - $63 \%$ of them have loans. Citizens 60 years of age and older (31\%) and young people aged 18 to 24 years (37\%) were less borrowed.

Most often take loans residents of villages and towns with a population of less than 100 thousand. People (56 and 55\%, respectively). We took a loan and 54\% of residents of cities with a population of 500 thousand. Up to 950 thousand. Man. Least of all people with loans in Moscow and St. Petersburg (40\%) [15].

Referring to the structure of credit debt of individuals.

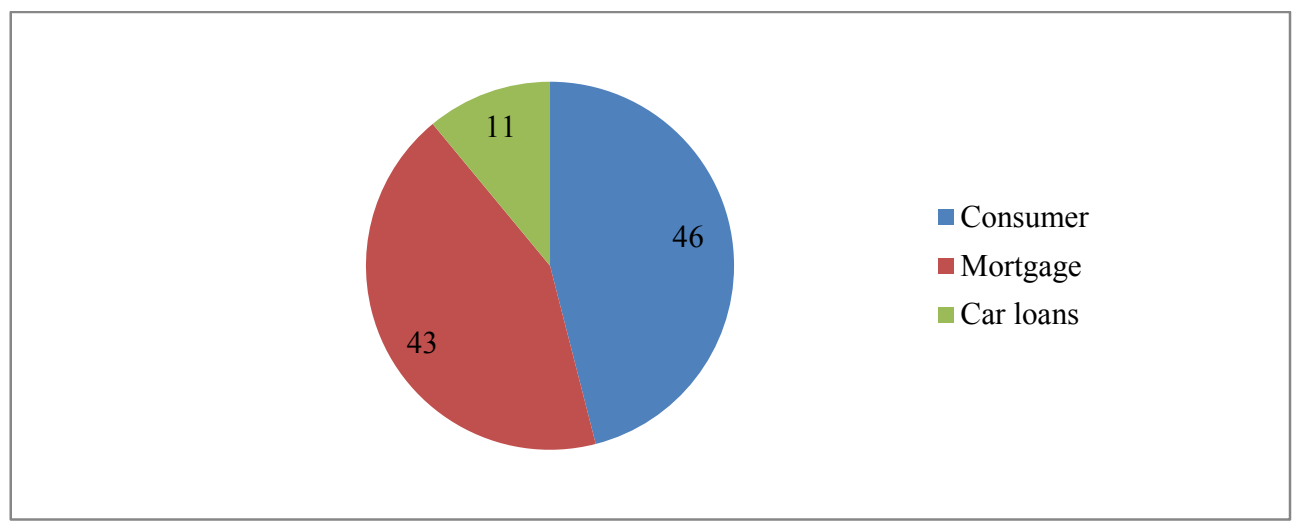

Fig. 2. Structure of credit debt of physical persons on January 1, 2018 (percentage).

In recent years, the volume of mortgage lending were increased and in 2018 almost equal to the size of consumer loans, although a few years earlier consumer lending is dominant. This is an indication of positive changes in the economy, as unsecured loans are much more risky for all parties credit relations, than the mortgage. Cash loans are often used for current needs and mortgages can be positioned as a long-term investment, contributing to social stability and economic growth [6].

Previously, we examined the borrowing of the population by bank loans. But more banks sufficiently scrupulous to take a decision on the approval of the loan the borrower, requesting documents confirming its solvency, determine the level of the debt burden, as the activities of banks closely monitored the main regulator, as The Central Bank is actively pursuing redevelopment policy [5]. In addition, with the October 1, 2019, banks are required to calculate the debt load index - the ratio of the ratio of monthly loan payments to income customer, the recommended rate of which shall not exceed $50 \%$, which is the barrier for the growth of debt load [4].

The greatest concern is the situation in the market of microfinance services. Microfinance institutions - a non-bank institutions engaged in issuing loans. The size of the loan, as a rule, does not exceed 30 thousand. For a potential borrower, contacting a microfinance organization, rather than a bank, is explained by such relative advantages as the speed of obtaining a loan, almost one hundred percent approval, a small amount of available 
documents (only a passport is enough). But the flip side of microfinance lending has visible flaws, because the MFI granted loans without assessing solvency of citizens, thus acquiring risk-downs, which it compensates for a huge percentage. At the same time among MFIs large share of swindlers.

However, the citizens will still apply to such organizations. Key market indicators of microfinance institutions showed an increase in the I quarter of 2019 compared to the same period last year. Micro-loan portfolio increased by $45 \%$ to $173.6 \mathrm{bln}$. Rubles volume quarterly issuance increased by $33.7 \%$ to 93.8 bln. Rubles.

On January 28 the daily interest rate on the loan may not exceed $1.5 \%$, and the maximum value of the fee for use of the loan (interest, penalties, additional services, etc.) - two and a half the size of the loan granted.

Microfinance institutions - leaders in the volume of issued micro-loans are presented in the table for 2018 [13].

Table 4. MFI - leaders in the volume of issued micro-loans for 2018.

\begin{tabular}{|c|c|c|c|c|}
\hline \multirow[t]{2}{*}{ A place } & \multirow[t]{2}{*}{ MFI name } & \multicolumn{2}{|c|}{ Displacement issuance } & \multirow{2}{*}{$\begin{array}{l}\text { The growth } \\
\text { rate in } 12 \\
\text { months. }\end{array}$} \\
\hline & & $\begin{array}{c}\text { Behind 2018, } \\
\text { mln. rubles }\end{array}$ & $\begin{array}{c}\text { During 2017, } \\
\text { mln. Rubles }\end{array}$ & \\
\hline 1 & $\begin{array}{l}\text { GK Eqvanta } \\
\text { (Bystrodengi } \\
\text { Turbozaym) }\end{array}$ & 12395.3 & 12080.5 & $3 \%$ \\
\hline 2 & Ezaem and Moneza & 9955.9 & 3790.1 & $163 \%$ \\
\hline 3 & MoneyMan & 7279.7 & 5144.4 & $42 \%$ \\
\hline 4 & Zaymer & 7181.7 & 3372.3 & $113 \%$ \\
\hline 5 & Webbankir & 5514.1 & 2003.4 & $175 \%$ \\
\hline 6 & MigKredit & 4853.2 & 6266.3 & $-23 \%$ \\
\hline 7 & $\begin{array}{l}\text { Arithmetic } \\
\text { (GK Russian Shoes) }\end{array}$ & 3400.3 & 3425.0 & $-1 \%$ \\
\hline 8 & IFC "pockets" & 3145.2 & 2559.6 & $23 \%$ \\
\hline 9 & Srochnodengi & 3048.5 & 2985.0 & $2 \%$ \\
\hline 10 & $\begin{array}{l}\text { GK Summit } \\
\text { (Summit and Dobrozaym) }\end{array}$ & 2958.0 & 2006.1 & $47 \%$ \\
\hline
\end{tabular}

Such volumes of issued loans is comparable to some of the banks, which indicates the strength of the positions occupied by the MFI about the super profits of the business.

Turning to the debt load of the population, it is worth noting that over the past two years, the amount of arrears, desperate to return, the Russians to microfinance institutions has increased by almost three times.

Currently, more than $60 \%$ of MFI borrowers have two operating microcredit, even $15 \%$ have three loan, and $25 \%$ have four or more credits. The average size of the micro-loans in 2018 grew by $4.7 \%$ compared with the previous period and reached 8200 rubles.

Due to this disappointing statistics, the Bank of Russia in 2019 began to conduct measures to regulate the activities of microfinance organizations. So, from July 2019 set the interest rate must not exceed $1 \%$ per day (365\% per year). other innovations are also introduced: limiting the maximum amount of the loan, the limit of fines, etc. MFIs, as well as the banks will need to calculate the index of the debt burden, but only in the issuance of loans in excess of 10 thousand rubles. All this should reduce the debt burden of the population, but it is obvious that even the rate of $365 \%$ per annum is very high and exceeds the bank tens of times.

The changes of the leverage by the National Bureau of credit histories that consolidates information on the order of 4000 Russian credits, including banks, MFIs, credit consumer cooperatives et al., Is shown in the diagram (Figure 3). Can see that for the six months from 
April to October 2019 the level of public debt load showed an increase of 1.64 percentage points. This indicator showed an increase for the first time since 2015, and its value as long as can be assessed as quite low. But despite this, the level of income of borrowers in a number of subjects of the Federation is not "comfortable" to service debt obligations and creditors should continue to closely monitor the risk profile of the borrowers with the help of real-time monitoring of their financial behavior [9].

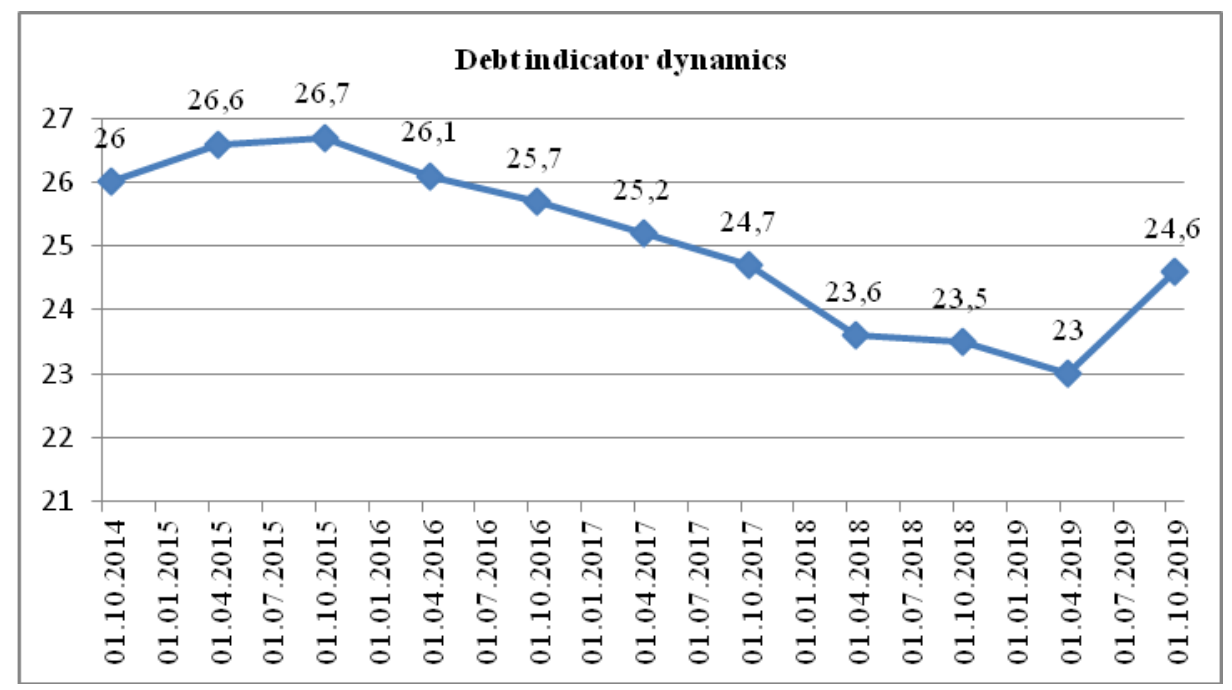

Fig. 3. The changes of the advantage (percentage) according NBCH.

As I stated earlier, with the necessary calculation of the indicator of debt burden of the borrower when granting loans was introduced October 1, 2019. Consumer finance market after a short period of time showed no significant changes due to innovations, but it seems that in 2020, the rate of growth in this segment will decline significantly. However, the indicators characterizing the lending to individuals in October were minimal in 2019, which could be the result of conducted reforms.

Table 5. Indicators characterizing lending to individuals in 2019.

\begin{tabular}{l|c|c|c|c}
\hline \multicolumn{1}{|c|}{2019} & $\begin{array}{c}\text { The volume of loans } \\
\text { granted to individuals } \\
\text { (mln. Rubles) }\end{array}$ & $\begin{array}{c}\text { Growth rate (the } \\
\text { past month), }\end{array}$ & $\begin{array}{c}\text { Total debt to } \\
\text { creditors of the } \\
\text { population } \\
\text { (mln. Rubles) }\end{array}$ & $\begin{array}{c}\text { Growth rate (the } \\
\text { past month),\% }\end{array}$ \\
\hline January & 901625 & - & 15005712 & - \\
\hline February & 982949 & 109 & 15190127 & 101.2 \\
\hline March & 1116877 & 113.6 & 15447995 & 101.7 \\
\hline April & 1206026 & 108 & 15760852 & 102 \\
\hline May & 1078437 & 89.4 & 16014495 & 101.6 \\
\hline June & 1117900 & 103.7 & 16241593 & 101.4 \\
\hline July & 1195032 & 107 & 16441253 & 101.2 \\
\hline August & 1229017 & 102.8 & 16745268 & 101.8 \\
\hline September & 1256319 & 102.2 & 17016415 & 101.6 \\
\hline October & 1270717 & 101.1 & 17077875 & 100.4 \\
\hline
\end{tabular}

Representatives of leading Russian banks believe that in 2020, the increase in lending to 
individuals will significantly decrease to about $12 \%$, and the main driver of growth will be the mortgage. In turn, the increase in the population's debt is projected to decrease by about 2 times. These provisions lead to the conclusion that if the forecast is true, the Central Bank's measures are indeed effective [16].

Thus, at the moment the level of debt load of the Russian population is not critical, but high enough. The main reasons for the growth of debt load will reduce the real income and low financial literacy. Compulsory calculation PDN for banks and microfinance institutions designed to stabilize the situation in the credit market, as a high level of public debt load and carries risks for the citizens and for the lenders, and the economy as a whole. The disadvantage of the indicator of debt burden is the fact that its high value does not necessarily mean the refusal to grant the loan.

In sum, it is possible to generate some recommendations to reduce the level of debt load of the population:

- $\quad$ to raise the living wage and the minimum wage;

- stabilize inflation;

- take measures to improve the financial literacy of citizens;

- develop mortgage lending;

- more strictly regulate the provisions regarding the leverage index (PDN);

- prohibit the granting of loans without proof of ability to pay.

\section{Conclusion}

Threats to improve Russian debt load of the population due to continued decline in real disposable income and the peak growth of unsecured lending, as well as the expansion of microfinance institutions. Now the debt burden indicators are Russian citizens within the limits may be adjusted. Therefore, the Central Bank measures were taken on time and can improve the situation in the segment of lending to individuals. So, the development of modern society is impossible without credit, but citizens need to make decisions on taking a loan, having weighed all the advantages and disadvantages of this transaction, and the state should not reduce the control work in this area.

\section{References}

1. O. V. Aseev, N. A. Mashkina, A. E. Veliyev, Bulletin of the Kursk State Agricultural Academy, 1, 141-146 (2019)

2. Bulletin on the current trends in the Russian economy, Dynamics of incomes of the population (2019)

3. A. I. Kovkuto, T. A. Svetovtseva, Collection of scientific articles of the 8th International Scientific and Practical Conference, 106-109 (2018)

4. Kommersant https://www.kommersant.ru/doc/4111135

5. V. I. Malanov, I. A. Yakovlev, D. Y. Burlov, Bulletin VSGUTU, 1 (64), 110-116 (2017)

6. S. A. Markina, P. A. Klimenko, N. A. Mashkina, SGEM International Multidisciplinary Scientific Conference on Social sciences and Arts, 1(4), 847-852 (2017)

7. N. A. Mashkina, S. A. Markina, P. V. Sergeev, Proceedings of the Southwestern State University, 3 (66), 138-144 (2016)

8. E. Belyaeva, O. Belyaeva, N. Mashkina, T. Polyakova, Proceedings of the 33rd International Business Information Management Association Conference, 1586-1593 (2019)

9. National Bureau of Credit Histories https://www.nbki.ru/ 
10. Popular Front https://onf.ru/2019/05/30/eksperty-onf-uroven-zakreditovannostirossiyan-za-1-kvartal-2019-goda-vyros-do-28/

11. The official website of the Central Bank of Russian Federation https://www.cbr.ru/eng/

12. The official website of the Federal State Statistics Service https://eng.gks.ru/

13. The rating agency "Expert" https://www.raexpert.ru/

14. E. Ershova, I. Ershova, T. Kolmykova, A. Devyatilova, Proceedings of the 33rd International Business Information Management Association Conference, 7319-7326 (2019)

15. RBC https://www.rbc.ru/

16. Akhmetshin, E. M., Plaskova, N. S., Iusupova, I. I., Prodanova, N. A., Leontyev, A. N., \& Vasilev, V. L. Data in Brief, 26 doi:10.1016/j.dib.2019.104532 (2019). 